\title{
HYPOGENIC FEATURES IN MARONIA CAVE, THRACE, GREECE. EVIDENCE FROM MORPHOLOGIES AND FLUID INCLUSIONS.
}

\author{
Vaxevanopoulos M. and Melfos V. \\ Aristotle University of Thessaloniki, Department of Mineralogy, Petrology, Economic Geology, \\ School of Geology, GR-541 24,Thessaloniki,Greece.vaxevan@geo.auth.gr,melfosv@geo.auth.gr
}

\begin{abstract}
The evolution of caves is usually controlled by meteoric water seepage into karst systems (epigenic process). In some cases, caves are formed by ascending fluids the aggressiveness of which is gained in depth. Such cavities are defined as hypogenic. Many caves considered previously as epigenic are now reinterpreted as hypogenic. Most Greek hypogenic caves are related with confined speleogenesis in karstic rocks near to impermeable rock exposures. At the present study the hypogenic features of the Maronia cave in Thrace of Greece, are described. The cave system is developed in a relatively thin layer of eroded Nummulitic limestones with a Middle Eocene age. Medium scale morphological characteristics such as cupolas and feeders indicate rising flow of solutions. In addition, fluid inclusion studies in selected calcite spars from the cave show elevated temperatures of formation (93 to $164^{\circ} \mathrm{C}$ with two peaks at 100 and $140^{\circ} \mathrm{C}$ ) from circulating hydrothermal fluids.
\end{abstract}

Key words: hypogenic caves, hydrothermal karst, Maronia cave, rising flow morphologies, fluid inclusions, Thrace, Greece.

\section{Introduction}

Most speleological studies were concerned with unconfined geologic settings and related to meteoric water recharge. Some explored cave systems in Greece display patterns, morphologies, sediments and minerals that do not correspond to established epigenic karst development and speleogenetic procedures. Hypogenism has different origin and characteristics comparing to epigenic processes. In most cases, this is totally climate independent (Klimchouk, 2007). Hypogenic caves are formed by water that recharges the soluble formation from below, driven by hydrostatic pressure or other sources of energy, independent of recharge from the overlying or immediately adjacent surface (Ford, 2006). They are often referred to as "thermal caves" or "sulphuric acid caves" due to their relation with thermal dissolutions containing sulphuric acid. Hypogenic caves are formed as well in seacoast mixing zones because the aggressiveness that forms them is generated below the surface by diffuse water that infiltrates directly into soluble rocks (Palmer, 2007).

Hypogenism is closely related with thermal waters and hydrothermal karst. The term hydrothermal karst refers to processes of dissolution of cavities and mineral precipitation therein by thermal waters (Dublyansky, 2005). The water must be several degrees warmer than the normal groundwater temperature of the surrounding region (at least $4^{\circ} \mathrm{C}$ ) in order to be classified as thermal (Scoeller, 1962). Conventionally, the temperature of $20^{\circ} \mathrm{C}$ is considered to be the lower limit of the thermal environment (Hölting and Coldewey, 2005). 


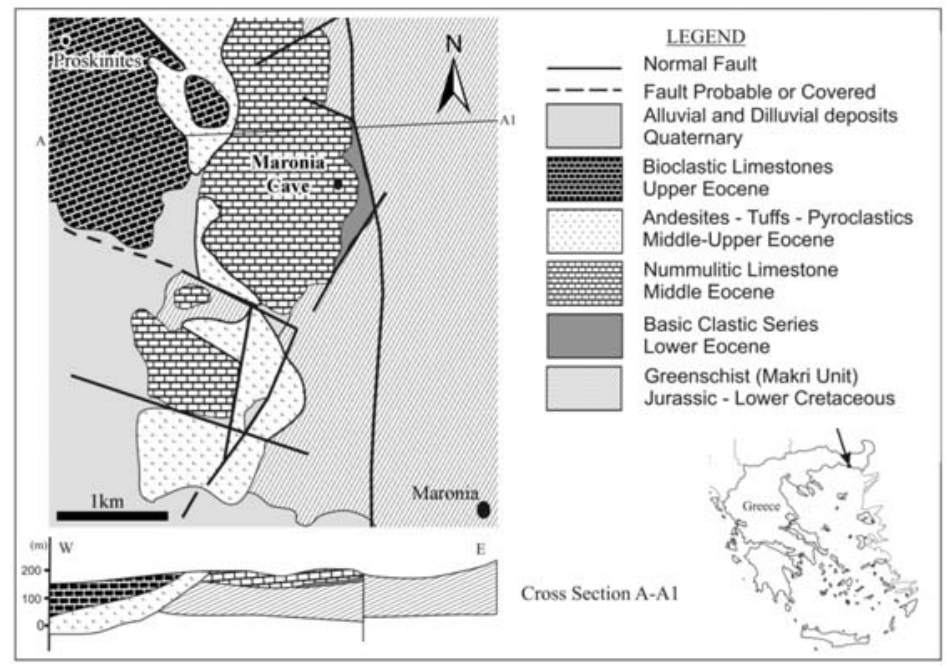

Fig. 1: Geologic map and cross section of Maronia Cave surrounding area (based on maps by Papadopoulos, 1982; Kouris, 1980; Melfos et al., 2005).

At the present study, morphological data from the Maronia cave are being described and genetically interpreted. Rising flow morphologies and fluid inclusions data imply thermal ascending solutions. Preliminary results of the fluid inclusion study are presented here in order to confirm this idea of the thermal environment during the speleogenesis. The purpose of this research is to demonstrate the mechanism for the deposition of calcite, forming the speleothems, and its physicochemical conditions in the context of the fluid inclusions data.

\section{Geological setting}

Maronia cave is located at the Koufoplati hill (3 km NW of the Maronia village) and developed in a relatively thin layer of eroded Nummulitic limestones of Middle Eocene age (Kouris, 1980; Papadopoulos, 1982; Melfos et al., 2005; Pavlides et al., 2008). These Nummulitic limestones have been unconformably deposited on top of the underlying Mesozoic greenschists of Makri and Drymos-Melia Units (Circum Rhodope geotectonic belt), and are spread over a wide area, covering today the top of the region hills (Fig. 1). The limestones are strongly fissured and fractured, slightly inclined towards the west and contain several species of fossilized foraminifera, algae, corals, sea urchins, bivalves and bryozoa. A basal clastic series partly defines the contact between limestones and the underlying greenschists. It comprises mainly conglomerates and sandstones and is considered to be the regression series marking the beginning of limestone deposition.

The greenschists of the Makri Unit are a complex of Jurassic-Lower Cretaceous metavolcanic rocks (lavas and tuffs) of low metamorphic grade. The Mesozoic metamorphic rocks and the Eocene limestones are intruded by Oligocene volcanic rocks, which, in the area of Maronia cave, are represented mainly by altered andesites alternating with bedded and partly unbedded tuffs. The andesites and the nummulitic limestones are overlain by up to $60 \mathrm{~m}$ thick bioclastic limestones of Upper Eocene age. The superficial microtectonic analysis has shown two main sets of joints: the primary one (D1) is striking $\mathrm{S} 20^{\circ} \mathrm{E}$ to $\mathrm{S} 30^{\circ} \mathrm{E}$ and comprises of long $(>10 \mathrm{~m})$ and quite sparsely $(\mathrm{ca} .0 .5 \mathrm{~m})$ developed joints, while the secondary one (D2) is striking $\mathrm{N}^{\circ} 0^{\circ} \mathrm{E}$ and comprises shorter joints (Pavlides et al., 2008). 


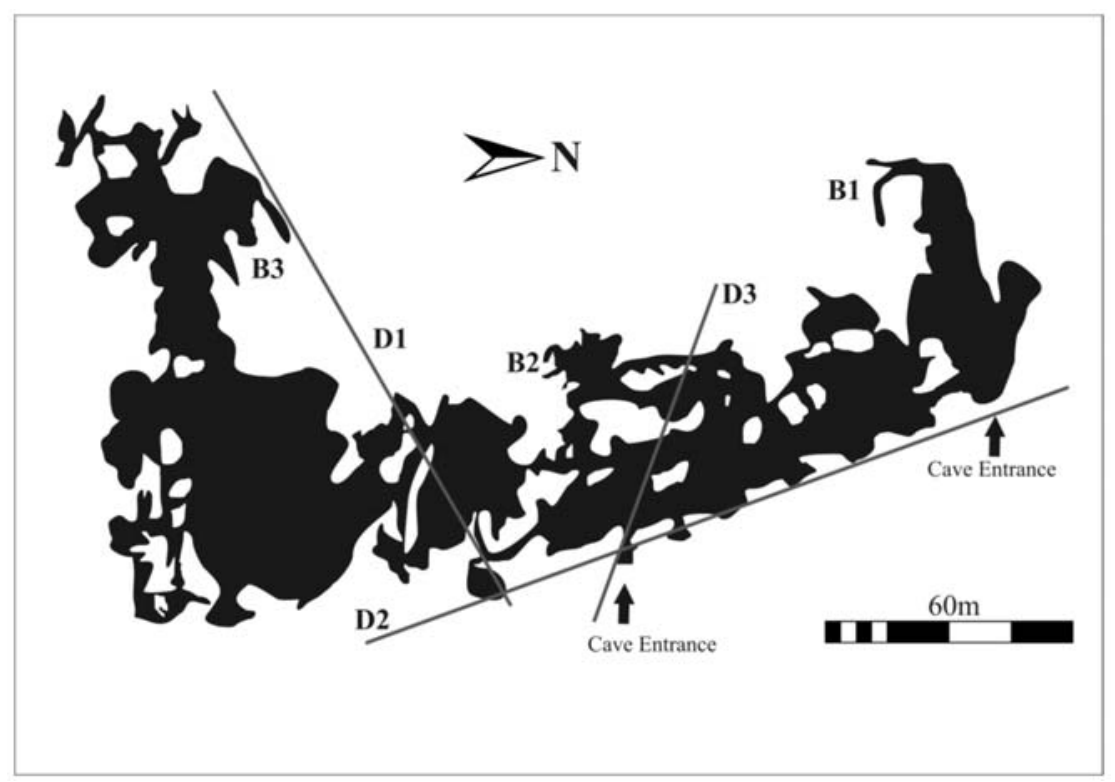

Fig. 2: Simplified plan of the Maronia cave (based on Petrochilou, 1984). The main tectonic lines depicted in map with D1, D2 and D3. A lot of blind terminations are also distinguished (B1, B2, B3).

\section{The Maronia Cave}

The Maronia cave presents a total passage length of approximately 2,000 meters and expands 10,000 square meters. There are two natural entrances to the cave, both on the eastern slope of the Koufoplati hill. The cave development is apparently controlled by the two main tectonic lines (D1 and D2). The primary one (D1) is trending NW-SE and forms the main axis of the cave chambers, while the other one (D2) is trending ENE-WSW and forms the secondary cave walls (Fig. 2). These lines are in good agreement with surface microtectonic analysis. A third tectonic line (D3), incising the older two, is striking $\mathrm{N} 110^{\circ} \mathrm{E}$ and constitutes the main cause of the south-eastern cave entrance development. The coincidence in strike between the two main joint systems, the cave chamber orientation and the tectonic lines of the near area, lead to the conclusion that the speleogenesis was controlled by these three main tectonic zones. These breaks seem to be the recharging ways of the hypogenic ascending waters. These tectonic lines are now being controlled by the vadose corrosion phenomena. Most of the cave ceiling is defined by the limestone low inclined strata.

Most of the floor surface is covered with calc-crust flowstone and sediment accumulations. The southern part of the cave comprises the largest chambers characterized by breakdown morphology. It has a great biological interest due to the presence of 11 different species of bats and 31 species of invertebrates. $1 / 3$ of this fauna consists of endemic species (Paragamian, 2004). The northern part of the cave has rather smaller champers with speleothems which have been affected by strongly corrosion processes. The stalactites of the ceiling of some chambers have collapsed.

Extensive calcite secondary deposits occur throughout the cave as common speleothems, such as stalactites, stalagmites, cave shields, draperies, flowstone, rimstone and coralloids, as well as less common such as helictites and mammilaries. The development of speleothems follows the main tectonic lines of the cave and is affected by the contemporary epigenic conditions. 


\section{Methods of analyses}

At the present research, several morphological characteristics of the Maronia cave were observed and analyzed. The macro-morphological analysis was based on the cave survey. In addition, medium scale features were observed in the cave interior and determined water flow directions.

Microthermometric data on four calcite speleothems were obtained using a LINKAM THM600/TMS 90 heating-freezing stage coupled to a LEITZ SM-LUX-POL microscope, housed at the Department of Mineralogy, Petrology, Economic Geology of the Aristotle University of Thessaloniki. Calibration of the stage was achieved using organic standards with known melting points (chloroform $-63.5^{\circ} \mathrm{C}$, naphthalene $80.35^{\circ} \mathrm{C}$, Merck $135135^{\circ} \mathrm{C}$, saccharine $228^{\circ} \mathrm{C}$, Merck $247247^{\circ} \mathrm{C}$ ) and ice $\left(\mathrm{H}_{2} \mathrm{O}\right)$. The precision of the heating and freezing measurements were $\pm 1^{\circ} \mathrm{C}$ and $\pm 0.2^{\circ} \mathrm{C}$, respectively. Fluid inclusion shapes and sizes, spatial relationships among inclusions and minerals and phases within inclusions were observed in five doubly-polished thin sections prepared at the University of Hamburg, Germany. Routine heating-freezing runs were performed on a total of 121 fluid inclusions. The FLINCOR program (Brown, 1989) was used to process the fluid inclusion data for calculating salinities and densities.

\subsection{Morphological criteria}

The macro-morphological analysis, based on the cave survey, indicates a relevant spongework maze pattern, with highly irregular passages interconnected with champers. This pattern is used in combination with the medium scale features in order to interpret the speleogenetical function. The mesomorphological features, including cupolas, roof pendants, partitions, dead ends and calcite spar geods situated in two different levels, display morphologic suite of uprising flow.

Cupolas are abundant in most parts of the cave (Fig. 3A). They are located mostly at the ceilings composing ceiling channels. They are rounded solution pockets indicating slow moving thermal water. They rarely indicate corrosion by condensation in convecting air. Some cupolas are hosted at inclined cave walls.

Pendants are residual pillars of rock between channels cut into ceiling and interpreted as bedding plane anastomoses or as pillars between closely-spaced paragenetic ceiling channels (Fig. 3A). The latter fits well to epigenetic processes as well. However, the hypogenic explanation best fits to the model of buoyancy currents rising from multiple feeders (Klimchouk, 2007). They have widespread occurrence at the southwestern part of Maronia cave. In many cases, they are covered by epigenetic speleothems (stalactites, coralloids). Feeders (inlets) are scattered found on the floor of the cave (Fig. 3B). Most of them are covered with clastic sediments. They represent basal input points of hypogenic solutions.

Calcite spar geodes are found at the central part of the cave (Fig. 3C). The crystals (dogtooth spars) have dimensions from 2 to $9 \mathrm{~cm}$ (main axis) and comprise fluid inclusions. Since 1930's, calcite spars, found in voids in carbonate rocks, were considered to be the product of descending meteoric karst waters, but detailed fluid inclusion studies by Ermakov (1945) on several cave deposits revealed the hydrothermal nature of this kind of calcite (Hill and Forti, 1997). Mammilaries are also phreatic speleothems usually formed by thermal waters. They comprise calcite coating at bedrock projections and they are often rimmed by coralloids or stalactites at the Maronia cave (Fig 3D).

Partitions and blind terminations are indicative of hypogenism (Fig. 3E). They are thin separations 


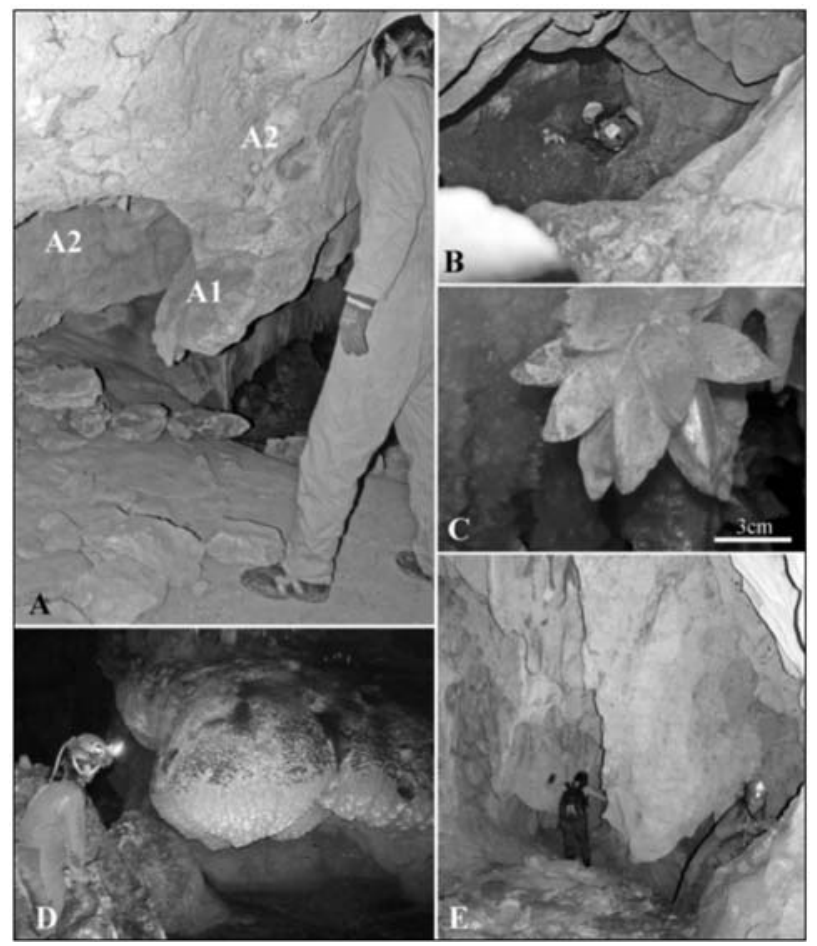

Fig. 3: Hypogenic features in Maronia Cave: A) View of the northern part of the cave, A1) Pendants, A2) Cupolas in cave walls, B) Caver inside a feeder, C) Calcite Spars, D) Mammilaries, E) Two separate partitions leading to dead-end with cupolas at the ceilings.

between adjacent passages or chambers formed by intense dissolution of the bedrock. Several blind passages are separated by partition walls. Blind terminations of passages in the Maronia cave can be clearly distinguished at the plan view of the figure 2 . They are widespread and formed by the enlargement of a single, isolated fracture.

\subsection{The fluid inclusions}

The fluid inclusion data were obtained from calcite spars which comprise the speleothems in the Maronia cave. Fluid inclusions were evaluated using fluid inclusion types and fluid inclusion assemblages (FIAs). FIAs are groups of inclusions of similar habit, having similar degree of filling (gas to liquid ratio) and showing similar, within $10^{\circ} \mathrm{C}$ to $20^{\circ} \mathrm{C}$, homogenization temperatures. This evaluation ensures that the results were not influenced by different sizes and shapes of fluid inclusions and it helps to eliminate variable data caused by changes after entrapment (Goldstein and Reynolds, 1994).

Fluid inclusions in the calcites of the Maronia cave have regular or irregular shapes (Fig. 4), and are isolated or are arranged in clusters and planes. Inclusions with negative crystal or rounded to elongated isometric shapes, which are mostly isolated, often occur along crystal faces of calcite. They are assumed to be primary in origin with only a few considered as secondary, according to the criteria of Roedder (1984) and Bodnar (2003). Microthermometric measurements were conducted mainly on primary fluid inclusions; inclusions that had been necked down or were secondary in origin were avoided. 

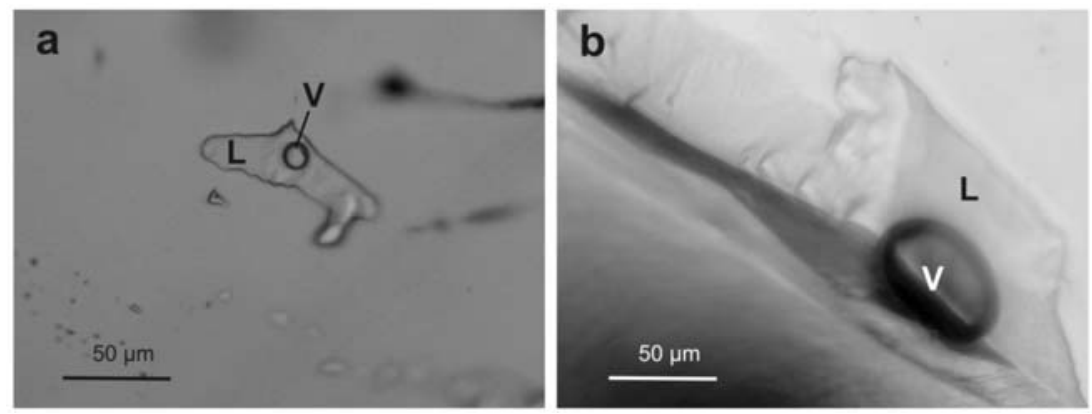

Fig. 4: Two-phase aqueous fluid inclusions $(a, b)$ in calcite from the Maronia hypogenic cave. L: Liquid, v: vapour.

Microthermometric results and compositional data from 121 fluid inclusions are depicted in Figs. 5 and 6. At room temperature, only two phase liquid-vapor inclusions were identified. Inclusions that were analyzed ranged in diameter between 9 and $105 \mu \mathrm{m}$ and in some cases they reached up to 500 $\mu \mathrm{m}$. They all homogenized into the liquid state. The primary fluid inclusions have relatively consistent liquid to vapor ratios (5-10 vol \% vapor). The variability in homogenization temperature data is due to real variability in the FIAs (Goldstein 2003).

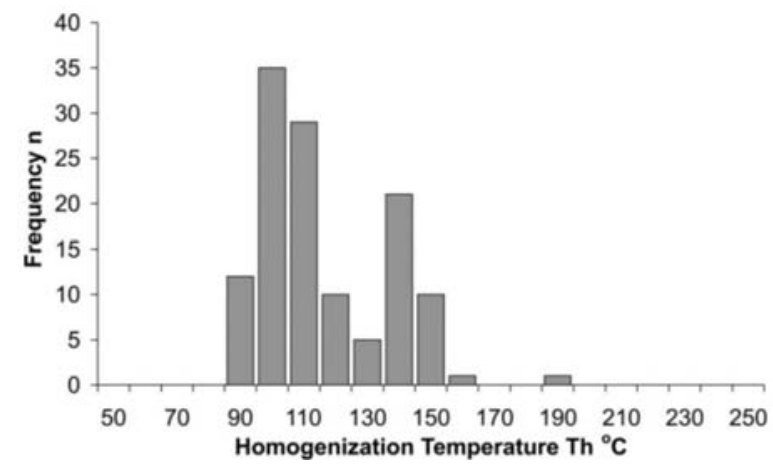

Fig. 5: Homogenization temperatures of two-phase liquid-rich aqueous fluid inclusions from the Maronia cave.

Homogenization temperatures of the fluid inclusions range mainly from $93^{\circ} \mathrm{C}$ to $164^{\circ} \mathrm{C}$, and show a bimodal peak at $100^{\circ} \mathrm{C}$ and $140^{\circ} \mathrm{C}$ (Fig. 5). Eutectic temperatures $\left(\mathrm{T}_{\mathrm{e}}\right.$ ) around $-21.4^{\circ} \mathrm{C}$ suggest that salts in the fluids are dominated by $\mathrm{NaCl}$ (Crawford 1981, Shepherd et al. 1985). The final ice melting temperatures range from $-0.1{ }^{\circ} \mathrm{C}$ to $-0.6^{\circ} \mathrm{C}$, corresponding to very low salinities between 0.2 and $1.0 \mathrm{wt} \% \mathrm{NaCl}$ equiv. Many inclusions in calcite can be grouped into FIAs which have a constant liquid to vapor ratios $(\sim 10 \%)$ and variable shapes, clustering along linear trends that do not cross cleavage or growth boundaries. FIAs showed restricted temperature ranges such as $93^{\circ} \mathrm{C}$ to $102^{\circ} \mathrm{C}$, $99^{\circ} \mathrm{C}$ to $124^{\circ} \mathrm{C}, 104^{\circ} \mathrm{C}$ to $114^{\circ} \mathrm{C}$ and $141^{\circ} \mathrm{C}$ to $156^{\circ} \mathrm{C}$, showing that the assemblages are true FIAs and, therefore, these ranges probably represent primary $\mathrm{T}_{\mathrm{h}}$.

\section{Discussion - Conclusions}

The majority of the hydrothermal karsts are attributed to $\mathrm{CO}_{2}$ from deep seated sources such as magmas or decarbonation reactions during rock metamorphism (Spötl et al., 2009). According to 


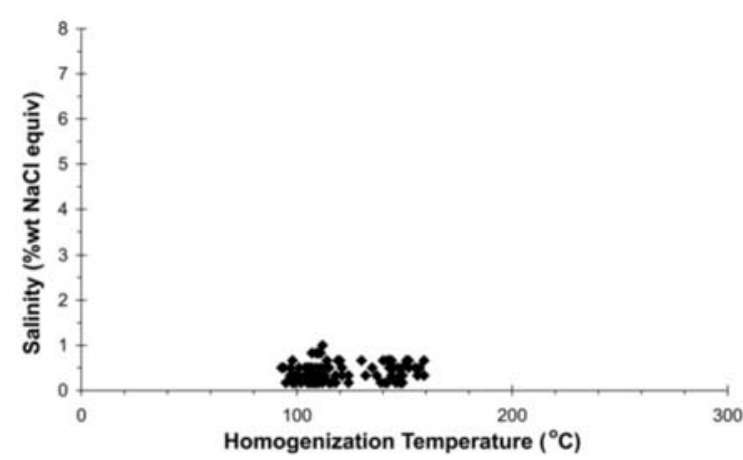

Fig. 6: Homogenization temperatures versus salinity plot for the fluid inclusions from the Maronia cave. Salinity was calculated using the equation of Potter et al. (1978) and Bodnar (1993).

Dublyansky (1995) thermal waters ascending from depth are saturated with respect to $\mathrm{CO}_{2}$ and become a potential factor in dissolution of carbonate rocks near the land surface or the ground water table. The upwelling warm waters are deeply circulating meteoric, and most rarely karst waters, which are connected with the precipitation of large calcite crystals in the karst systems, usually below the water table (Ford and Williams, 1989; Forti, 1996; Martini and Marais, 1996).

Based on the morphological features and the microthermometric studies the Maronia cave has been developed under hypogenic processes. Thermal ascending water is the main cause of morphological features such as cupolas, roof pendants, partitions, dead ends and calcite spar geods. Epigenic morphologies and sediment accumulation has masked these hypogenic elements.

The fluid inclusions in calcite from the Maronia hypogenic cave and the thermometric conditions derived from these inclusions, resemble those associated with hydrothermal karsts elsewhere (Bosák, 1998; Immenhauser et al., 2007; Spötl et al., 2009). It is therefore most reliable that the studied speleothems were formed at relatively high temperatures from $93^{\circ} \mathrm{C}$ to $164^{\circ} \mathrm{C}$, with two peaks at $100^{\circ} \mathrm{C}$ and $140^{\circ} \mathrm{C}$, supporting the assumption that the Maronia cave was formed under confined conditions in a geothermal convection system.

A hydrothermal derivation of the fluids is the most possible process for the calcites formation. The low salinities ( 0.2 and $1.0 \mathrm{wt} \% \mathrm{NaCl}$ equiv.) are possibly attributed to the circulation of downward migrating dilute meteoric water. Such a process is very likely in a hydrothermal environment of shallow depth, with fault-controlled vein structure. We estimated the pressure of the fluids, applying the Brown and Lamb (1989) equation of state to the microthermometric data of the $\mathrm{H}_{2} \mathrm{O}-\mathrm{NaCl}$ system. It is around 5 bars, indicating that the Maronia cave's last speleogenetical stages are located in a very shallow depth, very close to the surface. In this case pressure correction is not necessary and the homogenization temperatures correspond to actual trapping temperatures. Figure 6 shows a plot of the salinity data versus the homogenization temperatures for the liquid-rich aqueous fluid inclusions. From this diagram it is evident that the temperature decreases while the salinity remains constant. This implies that the temperature of the ascending fluids dropped from $164^{\circ} \mathrm{C}$ to $93^{\circ} \mathrm{C}$ without any change in their salinity. This episode was followed by cooling of the system due to the mixing of the warm with cold waters in shallow depths.

The andesite intrusion during the Upper Eocene forced the karstic aquifer to confined conditions. The thin carbonate unit was overlain by andesites and underlain by the impermeable strata of Makri unit's greenschists (Fig. 7). The early speleogenesis could be connected with the intrusion of the volcanic rocks in the area of the Maronia during Miocene. Small magmatic chambers generated the hydrothermal circulation and the convection of the meteoric waters in a geothermal system. Tectonism and uplift imposed fracture permeability which permitted thermal fluids to migrate upwards. 


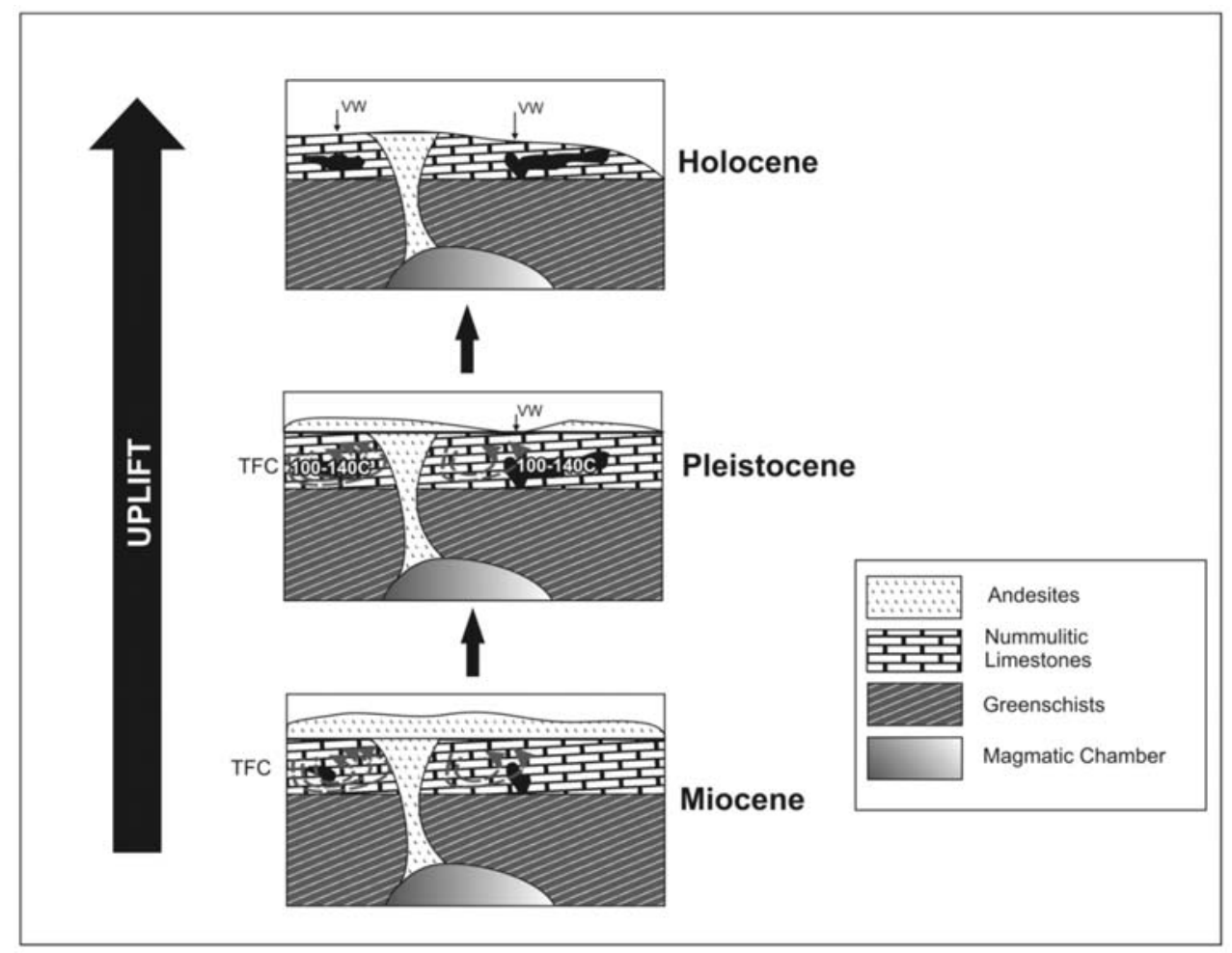

Fig. 7: Hypothesis on speleogenetical evolution of Maronia area. During Miocene the intrusion of andesites generates thermal fluid circulation (TFC) in the Nummulitic limestones that forms hypogenetic voids (confined karstic aquifer). In Pleistocene, meteoric water (VW) directly affects the phreatic conditions (unconfined karstic aquifer), while in Holocene is main cause for corrosion in vadose zone.

This function of thermal circulation formed small scale hypogenetic voids with integrated karstic conduits in phreatic conditions. The cavities were interconnected inside the confined karstic aquifer. Ascending thermal water was recharging the cave system through feeders and developed rapidly partitions, blind corridors and cupolas. The calcite spars were formed not until the phreatic conditions became swallower under the proccess of the area's uplift. This tectonic uplift led to vadose processes that mask the hypogenic features. The protective caprock has been entirely stripped under the Nummulitic limestones so vadose phenomena became more intense.Vadose corrosion is the only contemporary speleogenetical process in the Maronia cave. Moreover, breakdown morphology is taking place and develops the big cave chambers. The cave ceilings become thinner and consequently a new vertical entrance will be formed.

\section{References}

Bodnar, R.J., 1993. Revised equation and table for determining the freezing point depression of the $\mathrm{H}_{2} \mathrm{O}-$ $\mathrm{NaCl}$ solutions. Geochimica et Cosmochimica Acta, 57, 683-684.

Bodnar, R.J., 2003. Introduction to fluid inclusions. In I. Samson, A. Anderson and D. Marshall (eds), Fluid inclusions: analysis and interpretation. Mineral. Assoc. Canada, Short Course 32, 1-8.

Bosák, P., 1998. The evolution of karst and caves in the Koněprusy region Bohemian Karst, Czech Re- 
public), Part II: Hydrothermal paleokarst, Acta Carsologica, XXVII, 41-61.

Brown, P.E., 1989. FLINCOR: A microcomputer program for the reduction and investigation of fluid inclusion data, American Mineralogist, 74, 1390-1393.

Brown, P.E., and Lamb W.M. 1989. P-V-T properties of fluids in the system $\mathrm{H}_{2} \mathrm{O}-\mathrm{CO}_{2}-\mathrm{NaCl}$ : new graphical presentations and implications for fluid inclusions studies, Geochimica et Cosmochimica Acta, $53,1209-1221$.

Crawford, M.L., 1981. Phase equilibria in aqueous fluid inclusions. In:.Hollister, L.S., Crawford, M.L. (eds) Short course in fluid inclusions: applications to petrology, 75-100.

Dublyansky, Y.V., 1995. Speleogenetic History of the Hungarian Hydrothermal Karst, Environmental Geology, 25 (1), 24-35.

Dublyansky, Y.V., 2005. Hydrothermal caves. In D.C. Culver and W.B. White (eds), Encyclopedia of caves, Elsevier, Amsterdam, 300-304.

Ermakov, N.P., 1945. Geologicheskie uslovija formirovanija mestorozhdenij islandskogo shpata Srednej Azii (Geological conditions of formation of Iceland Spar deposits in Central Asia), Transact. of AllRussia Min.Soc., 74, 25-39.

Ford, D.C., 2006. Karst geomorphology, caves and cave deposits: A review of North American contributions during the past half century. In R.S. Harmon and C.W. Wicks (eds), Perspectives on Karst Geomorphology, Hydrology and Geochemistry. Geological Society of America, Special Paper, 404, 1-14.

Ford, D.C., and Williams P.W., 1989. Karst Geomorphology and Hydrology. Unwin Hyman. London. 601pp.

Forti, P., 1996. Thermal Karst Systems. Acta Carsologica, XXV, 99-117.

Goldstein, R., 2003. Petrographic analysis of fluid inclusions. In I.M. Samson, A.J. Anderson and D.D. Marshall (eds), Fluid inclusions: analysis and interpretation. Mineralogical Association of Canada, Short Course, 32, 9-53.

Goldstein, R.H., and Reynolds, T.J., 1994. Systematics of fluid inclusions in diagenetic minerals. SEPM Short Course 31, 199pp.

Hill, C., and Forti, P. 1997. Cave Minerals of the World. National Speleological Society, Huntsville, Alabama. 463pp.

Hölting, B., and Coldewey, W.G., 2005. Hydrogeologie. Einführung in die Allgemeine und Angewandte Hydrogeologie, 6th edn. Spektrum, Münich, 326pp.

Immenhauser, A., Dublyansky, Y.V., Verwer, K., Fleitman, D., and Pashenko, S.E., 2007. Textural, Elemental, and Isotopic Characteristics of Pleistocene Phreatic Cave Deposits (Jabal Madar, Oman), Journal of Sedimentary Research, 77, 68-88.

Klimchouk, A., 2007. Hypogene Speleogenesis. Hydrogeological and morphogenetic perspective. National Cave and Karst Institute. Sp.Paper, 1, 106pp.

Kouris, C., 1980. Geological map of Greece, Mesi-Xylagani sheet, scale 1:50.000. Institute of Geology and Mineral Exploration (IGME), Athens, Greece.

Martini, J.E.J., and Marais, J.C.E., 1996. Grottes hydrothermales dans le nord-ouest de la Namibie. Spéléogénèse et implication dans le développement des karsts en climat arid, Karstologia, 28, 13-18.

Melfos, V., Chatzipetros, A., Chatzopoulou, A., Vasileiadou, M.K., Lazarides, G., Vaxevanopoulos, M., Syrides, G., Tsoukala, E., and Pavlides S., 2005. Geological, petrographical and paleonotological study of the Maronia cave in the Eocenic limestones of Thrace. Bull. Greek Geol. Soc., 37, 153-167.

Palmer, N.A., 2007. Cave geology. Cave Books. Dayton, Ohio, 454pp.

Papadopoulos, P., 1982. Geological map of Greece, Maronia sheet, scale 1:50.000. Institute of Geology and Mineral Exploration (IGME), Athens, Greece. 
Paragamian, K., Nikoloudakis, E., Papadatou, E., and Sfakianaki, E., 2004. Biological-environmental study of Maronia Cave: analysis of current status-proposals. Greek Institute of Speleological Research, Irakleion, Greece, 112pp.

Pavlides, S., Tsoukala, E., Chatzipetros, A., Chatzopoulou, A., Melfos, V., Vasileiadou, M.K., Lazarides, G., and Vaxevanopoulos, M., 2008. The Maronia cave in the nummulitic limestone (Thrace, Greece). Geology \& Palaeontology. In Ch. Petreas (ed), Procceedings of the $14^{\text {th }}$ International Congress of Speleology (ICS), Athens, 88-90.

Petrochilou, A., 1984. Caves of Greece. Ekdotike Athenon, Athens, 160pp.

Potter, R.W., Clynne, M.A., and Brown, D.L., 1978. Freezing point depression of aqueous sodium chloride solutions. Economic Geology, 73, 284-285.

Roedder, E., 1984. Fluid Inclusions. Reviews in Mineralogy, 12, 646pp.

Shepherd, T., Rankin, A., and Alderton, D., 1985. A practical guide to fluid inclusion studies. Blackie and Son, Glasgow, 239pp.

Scoeller, H., 1962. Les eaux souterraines (Underground water). Paris, Mason and Cie, 642pp.

Spötl, C, Dublyansky, Y., Meyer, M., and Mangini, A. 2009. Identifying low-temperature hydrothermal karst and palaeowaters using stable isotopes: a case study from an Alpine cave, Entrische Kirche, Austria. International Journal of Earth Sciences, 98, 665-676. 